\section{Infertility specialists counsel caution over frozen eggs}

Helen Pearson, Philadelphia

Research advances that enable women's eggs and ovarian tissue to be frozen for

later use in assisted reproduction are not yet suitable for widespread adoption, says a report from the American Society for Reproductive Medicine (ASRM).

The methods "are by no means ready for prime time," Mark Fritz of the University of North Carolina at Chapel Hill, head of an ASRM committee that advises members on clinical practice, told the society's annual meeting in Philadelphia this week. Fritz said that doctors need to collect far more data on the health of children born through these methods before they become widely used.

A woman's fertility generally declines from puberty onwards, and more steeply from her thirties, as eggs are ovulated, die or deteriorate. Women with cancer and other illnesses can be rendered infertile much earlier if their eggs are damaged by chemotherapy or radiotherapy.

One way round this is to remove and freeze eggs before the treatment, for use later for in vitro fertilization. But doctors are still working out how to reliably prevent formation of damaging ice crystals in the eggs, and there have been fewer than 100 live births through this method. At least two US companies, however, offer women the chance to freeze their oocytes.

Another option still at the experimental stage is to remove and freeze entire slices of ovarian tissue, containing many eggs, and reimplant them later. Last month, doctors in Belgium announced the birth to a former cancer patient of the first baby produced by this technique.

The ASRM report 'Ovarian tissue and oocyte cryopreservation', is also published online this month in Fertility and Sterility $(82,993-998 ; 2004)$. It agrees that the techniques should be offered under strict supervision to cancer patients or other women who will be rendered infertile by medical treatment and who have few other options if they want children.

Before such techniques are offered to infertile but healthy women, the committee recommends that more data be gathered on any adverse effects on a woman's health or the risk of abnormalities or long-term health problems in her children. "Worldwide experience is simply insufficient at this time," Fritz says. The ASRM guidelines are not binding, but those in the field say that most US fertility clinics are expected to abide by them.

\title{
Early success claimed for Zerhouni's NIH roadmap
}

\section{Meredith Wadman, Washington}

It is just over a year since Elias Zerhouni, director of the National Institutes of Health (NIH), announced a far-reaching plan to transform key areas of biomedical research in the United States. And last week, the NIH director declared that his "roadmap" for the agency is bang on schedule.

"The roadmap has really taken hold," both inside and outside the NIH, Zerhouni said at a briefing held on 14 October to mark the anniversary. "We have made a lot of progress," Zerhouni said. He added that the biomedical agency's institutes and centres have responded to his \$2.2-billion, six-year blueprint with "enormous and amazing speed".

Outside observers have endorsed Zerhouni's upbeat assessment of the roadmap's progress. Grandiose plans in government often "seem to take for ever", notes David Moore, a lobbyist for the Association of American Medical Colleges (AAMC). "But they have gone in a relatively short time from the conceptual to actually having programmes in place."

At the briefing, Zerhouni provided a list of 192 roadmap project awards that have been made in 2004. But some observers are unsure that the project will outlast Zerhouni's tenure. A radiologist, Zerhouni is keen to align the NIH more closely with patients' immediate needs for medicines and technologies. This is a significant turnabout for an agency whose agenda has traditionally been driven by basic research in molecular biology.

But Zerhouni said that extramural researchers have met "every single" roadmap initiative with a more enthusiastic response than the NIH had expected. Some 1,000 researchers applied for nine extramural Pioneer Awards, which provide $\$ 500,000$ of funding each year for five years, with no strings attached.

The roadmap aims to get $\mathrm{NIH}$ institutes and centres to work towards three broad goals: better systems-biology tools; enhanced interdisciplinary team research; and accelerated clinical research to get discoveries from bench to bedside more quickly. The specifics include a network of biocomputing centres, new interdisciplinary research centres and innovative training for clinical researchers (see Nature 425, 438, 545; 2003).

The whole project is consuming less than $1 \%$ of the NIH's $\$ 27.8$-billion budget, including $\$ 129$ million in 2004. "But it is an important percentage," Zerhouni said last week, "because it's what we call 'risk money'."

Moore says that the plan is being supported

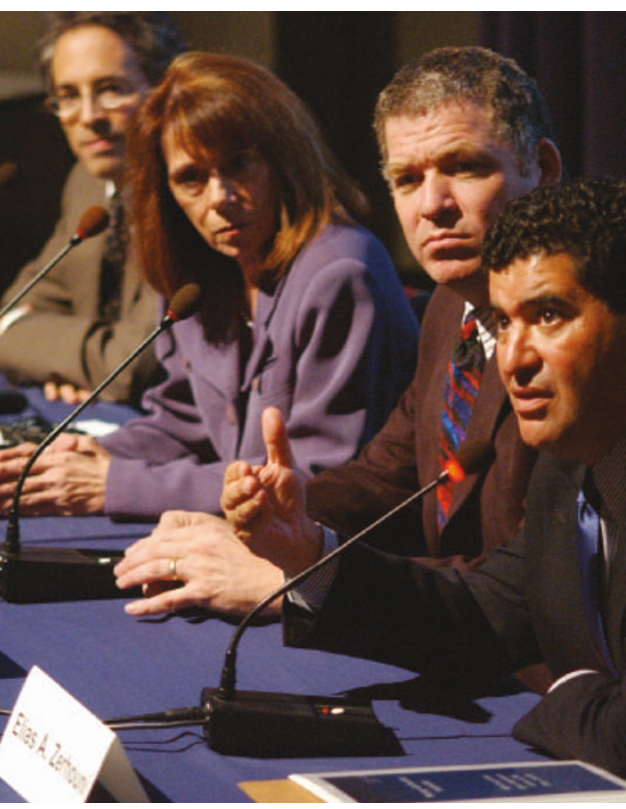

On target: Elias Zerhouni (right) and institute heads.

in the Congress. The feeling among legislative staffers is that it "is giving a direction to the NIH", he says. "It's not just more of the same."

Anthony Means chairs the department of pharmacology and cancer biology at Duke University Medical Center in Durham, North Carolina, where researchers have won seven roadmap grants this year. Means says that, as president of the Endocrine Society, he backs the roadmap because of its emphasis on getting basic science discoveries to patients. For the first time in his 30 years in science, Means says, he's hearing an NIH director clearly say: "If you expect to be funded by the NIH, you're going to have to be willing to consider the application of the science that you're doing."

That message has met with mixed reviews from investigators, Means adds: "Some people have taken to it pretty well. And others say they don't want to be told how to do science."

Still others are sceptical that, in an era of essentially flat NIH funding, the roadmap can outlive Zerhouni's tenure. "There is some fear that it won't be a sustainable thing," says Tony Mazzaschi, associate vicepresident for research at the AAMC. Mazzaschi points out that the initiative's funding is predicated on voluntary yearly contributions from all 27 NIH institutes and centres. When funding gets tight, and the choice is between funding a roadmap initiative and an institute's own best research grant proposals from individual investigators, Mazzaschi says, "some of these cross-institute initiatives may be a lesser priority for a given institute. As they say, 'all politics is local'.' 